\title{
Temporal Changes in Lesser Kestrel (Falco naumanni) Diet During the Breeding Season in Southern Spain
}

Author(s) :Carlos Rodríguez, Luis Tapia, Florian Kieny, and Javier Bustamante Source: Journal of Raptor Research, 44(2):120-128. 2010.

Published By: The Raptor Research Foundation

DOI: http://dx.doi.org/10.3356/JRR-09-34.1

URL: http://www.bioone.org/doi/full/10.3356/JRR-09-34.1

BioOne (www.bioone.org) is a nonprofit, online aggregation of core research in the biological, ecological, and environmental sciences. BioOne provides a sustainable online platform for over 170 journals and books published by nonprofit societies, associations, museums, institutions, and presses.

Your use of this PDF, the BioOne Web site, and all posted and associated content indicates your acceptance of BioOne's Terms of Use, available at www.bioone.org/ page/terms_of_use.

Usage of BioOne content is strictly limited to personal, educational, and noncommercial use. Commercial inquiries or rights and permissions requests should be directed to the individual publisher as copyright holder. 


\title{
TEMPORAL CHANGES IN LESSER KESTREL (FALCO NAUMANNI) DIET DURING THE BREEDING SEASON IN SOUTHERN SPAIN
}

\author{
CARLOS RODRÍGUEZ \\ Department of Wetland Ecology, Doñana Biological Station, C/ Americo Vespucio s/n, Isla de la Cartuja, \\ 41092 Sevilla, Spain \\ LUIS TAPIA ${ }^{1}$ \\ Department of Zoology and Physical Anthropology, University of Santiago de Compostela, \\ 15782 Santiago de Compostela, Spain \\ and \\ Department of Wetland Ecology, Doñana Biological Station, C/ Americo Vespucio s/n, Isla de la Cartuja, \\ 41092 Sevilla, Spain
}

\author{
FLORIAN KIENY AND JAVIER BUSTAMANTE \\ Department of Wetland Ecology, Doñana Biological Station, C/ Americo Vespucio s/n, Isla de la Cartuja, \\ 41092 Sevilla, Spain
}

\begin{abstract}
We examined changes in diet composition during the breeding period for the endangered Lesser Kestrel (Falco naumanni). Pellets were collected weekly from the last week of March until the first week of July in a colony located in southwestern Spain. Diet composition was evaluated in terms of frequency of occurrence of different prey, mean prey weight, and prey richness of each pellet. Generalized additive models were used to analyze the predictive ability of calendar week (as an index to prey availability), reproductive week (as an index to breeding demands), and nest identity (as a proxy for individual preferences/abilities) on the above dietary metrics. Primary prey species were the mole cricket (Gryllotalpa gryllotalpa) during courtship, the saddle-backed bush cricket (Ephippiger ephippiger) during incubation, and the migratory locust (Locusta migratoria) and the white-faced bush-cricket (Decticus albifrons) during the nestling phase. Small mammals were only important during some particular weeks at the beginning of the nestling period. Mean prey weight increased as the breeding season advanced, while species richness tended to decline. This was mainly due to the decreasing contribution of small prey items such as beetles to the diet and the greater incidence of large prey species. Calendar week and reproductive week had similar abilities to predict diet composition, and were better predictors than nest identity. Models fitted to particular prey species had greater explanatory power than models fitted to prey groups. Likewise, models fitted to those prey species that we considered "preferred" fitted better than those considered "refuge" prey.
\end{abstract}

KeY Words: Lesser Kestrel; Falco naumanni; diet; pellet analysis; phenology.

\section{CAMBIOS TEMPORALES EN LA DIETA DE FALCO NAUMANNI DURANTE EL PERIODO REPRODUC- TIVO EN EL SUR DE ESPAÑA}

\begin{abstract}
RESUMEN.-Se examinaron los cambios en la composición de la dieta de la especie de cernícalo amenazada Falco naumanni a lo largo del ciclo reproductivo. Se recogieron egagrópilas semanalmente desde la última semana de marzo hasta la segunda semana de julio en una colonia situada en el suroeste de España. La dieta se evaluó en términos de la composición de presas, el peso medio de las presas y la riqueza de presas por egagrópila. Se utilizaron modelos aditivos generalizados para analizar la capacidad explicativa de la semana calendario (como indicador de la disponibilidad de presas), la semana reproductiva (como indicador de la demanda reproductiva) y el nido (como indicador de posibles preferencias individuales) sobre los descriptores de la dieta antes mencionados. Las principales presas fueron Gryllotalpa gryllotalpa durante el cortejo, Ephippiger ephippiger durante la incubación y Locusta migratoria y Decticus albifrons durante el crecimiento de los pollos. Los micromamíferos fueron importantes sólo durante algunas semanas, como
\end{abstract}

\footnotetext{
${ }^{1}$ Email address: Luis.tapia@usc.es
} 
la primera del crecimiento de los pollos. El peso medio de las presas aumentó a lo largo del periodo reproductivo, mientras que la riqueza de presas tendió a disminuir. Esto fue fundamentalmente debido a una disminución paulatina de especies de pequeño tamaño como los escarabajos y a la mayor constancia de presas de mayor tamaño. La semana reproductiva y la semana calendario mostraron capacidades explicativas similares, mientras que el nido explicó mucho menos los cambios en la dieta. Los modelos ajustados a especies de presas determinadas fueron mejores que los construidos para grupos de presas. De igual modo, los modelos construidos para especies preferidas se ajustaron mejor que los elaborados para especies "refugio."

[Traducción del equipo editorial]

Diet studies are important for understanding different aspects of raptor foraging ecology, and their conclusions are frequently applicable in the management of raptor populations (Marti et al. 2007). Feeding behavior may vary by sex, age, habitat, and season, with important consequences for populations (Newton 1998). For example, breeding raptors may adjust their foraging behavior, habitat, or prey selection to compensate for the increased daily energetic requirements of reproduction (Newton 1979). The reproduction of raptors strongly depends on food availability and patterns of variations in breeding success are often associated with variations in food supply (Dijkstra 1988, Newton 1979, 1998). This is particularly important in insectivorous raptors that depend heavily on insect population outbreaks. Because reproduction imposes some energetic constraints, such species may adjust their breeding phenology to take advantage of peaks in prey populations (see Newton 1998).

The Lesser Kestrel (Falco naumanni) is a small (body length 29-32 cm, wingspan 58-72 cm) colonial falcon that breeds in holes and crevices in large urban buildings (such as churches and castles), and in farmhouses in the countryside, as well as on cliffs (Negro 1997). It inhabits steppe-like ecosystems around the Mediterranean and central Asia. The species is currently listed within the top category of Species of European Conservation Concern (BirdLife International 2004), due to population declines. The reduction in both the extent and quality of foraging habitats in its western Palearctic breeding range appears to be the primary cause of population decline (Peet and Gallo-Orsi 2000). This is apparently true for the study population (southwestern Spain), where starvation is the primary cause of nestling mortality (Negro 1997).

Lesser Kestrel diet has been studied in different countries and seasons (Spain: Franco and Andrada 1977, Rodríguez 2004; Portugal: Rocha 1998; France: Choisy et al. 1999, Lepley et al. 2000; South Africa: Anderson et al. 1999, Kok et al. 2000, Kopij 2007). Most of the work indicates that Lesser Kes- trels are primarily insectivorous, feeding mainly on beetles, myriapods and grasshoppers in Europe, but also on termites and solifuges in their wintering grounds. However, ours is the first study focusing on weekly changes in diet composition during the breeding season and whether diet in different times of the breeding season may suggest limitations in prey availability for this endangered species.

\section{Study AREA AND Methods}

Study Area. We studied the Lesser Kestrel colony located in the grain elevator of La Palma del Condado (Huelva Province, southwestern Spain), where individuals nest on windowsills that are sheltered and sufficiently enclosed to make a suitable nesting site. Nests were monitored from inside the building. This colony is located in the Guadalquivir alluvial plain, which is predominantly flat (elevation range 20-240 m) and dominated by agricultural fields and a few other vegetation types (mainly open holm oak [Quercus ilex] woodland; Fernández et al. 1992). Primary crops are cereals and sunflowers. Cotton crops, olive groves, and vineyards are also present in the area.

Pellet Collection. We collected 204 pellets at 16 different Lesser Kestrel nests in the colony. After removing all old prey remains and pellets from nests, fresh pellets were collected weekly from 31 March to 14 July 2003 (from pair formation to fledging). Because pellet analyses of insectivorous birds may be time-consuming, we collected a sample from some nests: a minimum of 12 pellets per week. Because not all pairs that were present at the colony at the beginning of the breeding season bred successfully or did it in the nests we have previously cleaned from old remains, we were not able to collect pellets continuously from all focal nests. Therefore, most information came from five nests (mean number of pellets per nest: $12.75 \pm 10.9$ [SD]).

Prey Identification. For each pellet, we assigned identifiable remains to different taxa using field and taxonomic guides (Chynery 1988, Clemente et al. 1987, Zahradnik 1990), a reference collection 
NEST

6E3

$6 S 1$

$6 N 1$

$7 \mathrm{~S} 1$

$6 \mathrm{E} 1$

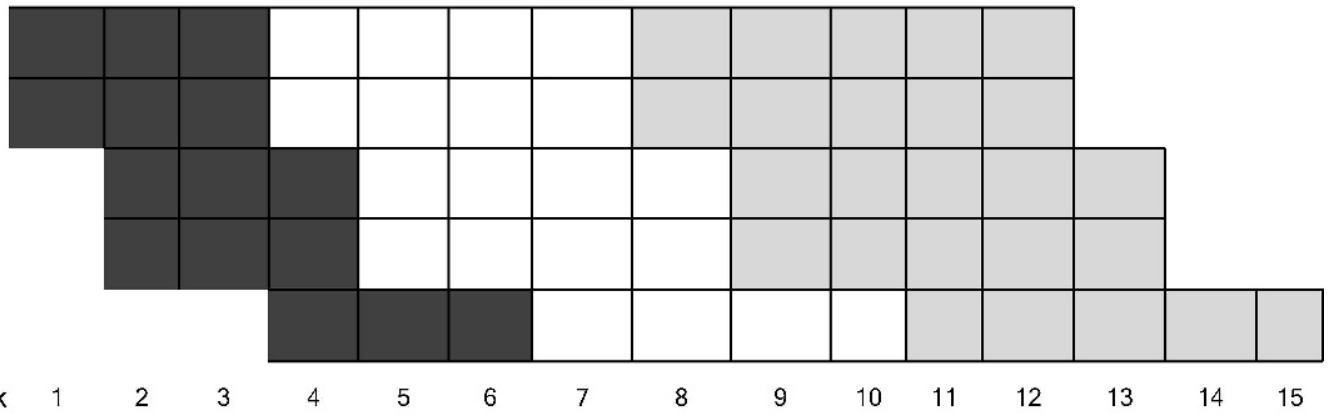

Date

31-Mar 7-Apr 14-Apr 21-Apr 28-Apr 5-May 12-May

19-May 26-May 2-Jun 9-Jun 16-Jun 23-Jun 30-Jun 7-Jul

Figure 1. Schematic representation of the breeding phenology of analyzed nests. Different colors correspond to courtship (dark grey), incubation (white) and nestling phase (light grey) of each nest. Both date and the correspondent calendar week have been included.

(mainly of grasshoppers) from the study area (see Rodríguez and Bustamante 2008), and expert opinion on digital photos of some remains. A conservative criterion was applied, so many prey remains were assigned only to family or genus level. The number of individual prey items in each pellet was calculated based on the number of same-side anatomical remains found for each taxon in the pellet. Because vertebrates are only partially ingested (head, tail, and back skin are often discarded) and insectivorous raptors have strong digestive systems, few teeth or bones were available for identification. Thus, the presence of hair in the pellet was the main indicator of mammals' consumption. Because hairs may also appear in pellets as contamination from the nest (by sticking to the pellet when it is regurgitated) or as stomach residual, we considered one mammal prey item eaten if the estimation of the volume proportion of hair in a pellet was $>10 \%$ of all remains. Using this criterion, we assumed no real consumption of mammals for 13 pellets, 5 of which were close to the threshold value of $10 \%$ volume.

Statistical Analyses. We built generalized additive models (GAMs; Hastie and Tibshirani 1990) on the frequency of occurrence of food items in each pellet, mean prey weight, and prey richness. For the frequency of occurrence, we built a vector considering the number of items belonging to a prey category and the total number of prey items in the pellet. Models were fitted by using binomial error and logit link (Crawley 2002). For each pellet, we calculated its mean prey weight, based on prey masses from our study area (see Rodríguez and Bustamante 2008) and published data (Franco and Andrada
1977, Choisy et al. 1999, Lepley 2000). This estimation took into account dimorphic species (e.g., Calliptamus spp. in which females are much larger than males), and different development states of some species (e.g., E. ephippiger). We also estimated prey richness by considering the number of different prey taxa occurring in the pellet. For these variables we used normal and Poisson errors, respectively. As explanatory variables we considered both calendar week (as the number of weeks from 1 January) and reproductive week (number of weeks from egg-laying; Fig. 1). Nest identity was included as a single explanatory variable or in combination with either of the above variables.

For GAM analyses, we used the subset of five nests with the best distribution of sample size throughout the study period (Fig. 1). Models initially included all the predictors in their linear or smoothed form (smoothing splines with two to four degrees of freedom for non-categorical variables), and were refined using backward stepwise analysis. At every step, we tested the significance of variables by a likelihood ratio test of the current full model versus the reduced model without each particular variable. We also tested whether increasing degrees of freedom of splines increased explanatory power of models. We also calculated AIC values to ascertain whether explanatory power should be penalized by the complexity of the model. Because the lack of complete independence between nest and reproductive week (see Fig. 1) made interactions difficult to interpret biologically, we considered only those bivariate models with nonsignificant interactions. Competing models for the same response variable were evaluated 
Table 1. Frequency of occurrence and contribution in terms of biomass of prey items found in the 204 Lesser Kestrel pellets analyzed. Taxonomic hierarchy among taxa is denoted by means of different indentation and lettering. Totals for main groups are included.

\begin{tabular}{|c|c|c|c|c|c|}
\hline TAXON & PREY Item & FREQUENCY & $\%$ & $\begin{array}{c}\% \text { OF TOTAL } \\
\text { BIOMASS }\end{array}$ & $\begin{array}{l}\text { INDIVIDUAL } \\
\text { BIOMASS }(\mathrm{g})\end{array}$ \\
\hline Arthropoda & Unidentified & 263 & 9.0 & 1.9 & \\
\hline Arachnida & Unidentified & 21 & 0.7 & 0.2 & 0.20 \\
\hline \multirow[t]{3}{*}{ Chilopoda } & & 27 & 0.9 & 1.4 & \\
\hline & Scolopendra cingulata & 16 & 0.5 & 1.4 & 2.30 \\
\hline & Scutigera $\mathrm{sp.}$ & 11 & 0.4 & 0.0 & 0.10 \\
\hline Coleoptera & & 1042 & 35.6 & 9.1 & 0.24 \\
\hline Dermaptera & & 90 & 3.1 & 0.3 & 0.09 \\
\hline Hemiptera & & 32 & 1.1 & 0.4 & 0.30 \\
\hline \multicolumn{6}{|l|}{ Hymenoptera } \\
\hline Formicidae & & 214 & 7.3 & 0.2 & 0.02 \\
\hline Lepidoptera & & 80 & 2.7 & 0.4 & 0.12 \\
\hline Orthoptera & Unidentified & 3 & 0.1 & 0.1 & \\
\hline \multirow[t]{5}{*}{ Acrididae } & Unidentified & 41 & 1.4 & 0.6 & \\
\hline & Aiolopus spp. & 62 & 2.1 & 0.6 & 0.27 \\
\hline & Anacridium aegyptium & 57 & 1.9 & 6.9 & 3.27 \\
\hline & Calliptamus spp. & 26 & 0.9 & 0.7 & 0.74 \\
\hline & Locusta migratoria & 71 & 2.4 & 3.6 & 1.38 \\
\hline Gryllidae & Gryllus spp. & 227 & 7.8 & 5.6 & 0.67 \\
\hline Gryllotalpidae & G. gryllotalpa & 78 & 2.7 & 10.1 & 3.50 \\
\hline \multirow[t]{4}{*}{ Tettigonidae } & Unidenified & 16 & 0.5 & 0.7 & \\
\hline & Decticus albifrons & 86 & 2.9 & 9.7 & 3.07 \\
\hline & Ephippiger ephippiger & 371 & 12.7 & 27.1 & 1.98 \\
\hline & Platycleis spp. & 69 & 2.4 & 2.7 & 1.06 \\
\hline Total Orthoptera & & 1107 & 37.8 & 68.4 & \\
\hline Total Arthropoda & & 2876 & 98.3 & 82.2 & \\
\hline \multicolumn{6}{|l|}{ Chordata } \\
\hline \multicolumn{6}{|l|}{ Esquamata } \\
\hline Lacertidae & Psammodromus spp. & 3 & 0.1 & 0.3 & 3.0 \\
\hline Rodentia & Unid. Rodentia & 48 & 1.6 & 17.5 & 9.87 \\
\hline Total Chordata & & 51 & 1.7 & 17.8 & \\
\hline
\end{tabular}

by means of AIC weights (ranging from 0 to 1 , with higher values signifying better models). The AIC weight indicates the probability that the model was the best among the set of candidate models (Johnson and Omland 2004). We considered that there was more than one competing model when the greatest AIC weight was $<0.99$. We used R-software and S-plus (Mathsoft, Inc. 1999) to conduct all analyses.

\section{REsults}

We identified 2927 prey items (103 \pm 91 items per nest), from which we considered the following groups: Acrididae (grasshoppers), Coleoptera (beetles), Gryllidae (crickets), Gryllotalpa gryllotalpa (mole cricket), Tettigonidae (bush crickets), and vertebrates (Table 1). A total of 727 prey items (22 \pm 21 per nest) of small size and ephemeral importance were classified as "others," including ants, moth bugs, earwigs, and other unidentified invertebrates. In six pellets from the first calendar week of the breeding period we also found earthworm chaetae, which were not included in Table 1 because only presence/absence of this prey item could be determined. Among Acrididae and Tettigonidae, we were able to distinguish four, and three prey species, respectively (Table 1). However, beetles could be identified to the genus or species level less frequently and were analyzed as a group.

The consumption of nearly all prey groups showed temporal fluctuations. Calendar week was, 
Table 2. Significance and percentage explained deviance (E.D.) by the AIC-selected form of each predictor of prey category occurrence in Lesser Kestrel pellets. Models for both main prey groups and individual prey species are shown. The best model and its E.D. are also indicated. Terms fitted with a smooth spline are denoted with an "s" before them, the exponent indicating the degrees of freedom of the spline. In case of competing models, AIC weights for each of them are also provided. Significance key: $* * *=<0.001 ; * *=<0.01 ; *=<0.05$; N.S. $=$ nonsignificant.

\begin{tabular}{|c|c|c|c|c|c|c|}
\hline Prey Category & $\begin{array}{l}\text { CALENDAR } \\
\text { WEEK }\end{array}$ & $\begin{array}{l}\text { REPRODUCTIVE } \\
\text { WEEK }\end{array}$ & Nest ID. & Best Model & E.D. & $\begin{array}{c}\text { AIC } \\
\text { WEIGHT }\end{array}$ \\
\hline Acrididae & $30 \% * * *$ & $9 \% * *$ & $15 \% * * *$ & s(Cal. week $)^{4}$ & $30 \%$ & - \\
\hline Locusta migratoria & $44 \% * * *$ & $41 \% * * *$ & N.S. $6 \%$ & $\begin{array}{l}\mathrm{s}(\text { Cal. week })^{4} \\
\mathrm{~s}(\text { Rep. week })^{4}\end{array}$ & $\begin{array}{l}44 \% \\
41 \%\end{array}$ & $\begin{array}{l}76.93 \% \\
23.07 \%\end{array}$ \\
\hline Coleoptera & N.S. $1 \%$ & N.S. $1 \%$ & N.S. $5 \%$ & s(Cal. week $)$ & $1 \%$ & - \\
\hline Gryllidae (mainly Gryllus campestris) & $20 \% * * *$ & $19 \% * * *$ & N.S. $7 \%$ & $\mathrm{~s}(\text { Cal. week })^{4}+$ nest & $26 \%$ & - \\
\hline Gryllotalpa gryllotalpa & $46 \% * * *$ & $41 \% * * *$ & $17 \% * * *$ & $\mathrm{~s}(\text { Cal. week })^{4}+$ nest & $62 \%$ & - \\
\hline Tettigonidae & $44 \% * * *$ & $43 \% * * *$ & $9 \% *$ & $\mathrm{~s}(\text { Cal. week })^{4}+$ nest & $52 \%$ & - \\
\hline Ephippiger ephippiger & $47 \% * * *$ & $48 \% * * *$ & $8 \% *$ & $\begin{array}{l}\mathrm{s}(\text { Cal. week })^{4}+\text { nest } \\
\mathrm{s}(\text { Rep. week })^{4}+\text { nest }\end{array}$ & $\begin{array}{l}55 \% \\
55 \%\end{array}$ & $\begin{array}{l}39.65 \% \\
60.35 \%\end{array}$ \\
\hline $\begin{array}{l}\text { Decticus albifrons } \\
\text { Platycleis ssp. }\end{array}$ & $\begin{array}{l}55 \% * * * \\
49 \% * * *\end{array}$ & $\begin{array}{l}64 \% * * * \\
37 \% * * *\end{array}$ & $\begin{array}{l}20 \% * * \\
19 \% * * *\end{array}$ & $\begin{array}{l}\text { s }(\text { Rep. week })^{4} \\
\mathrm{~s}(\text { Cal. week })^{4}+\text { nest }\end{array}$ & $\begin{array}{l}64 \% \\
52 \%\end{array}$ & - \\
\hline Vertebrata & $17 \% * * *$ & $17 \% * * *$ & N.S. $3 \%$ & $\begin{array}{l}\mathrm{s}(\text { Cal. week })^{2} \\
\mathrm{~s}(\text { Rep. week })^{2}\end{array}$ & $\begin{array}{l}17 \% \\
17 \%\end{array}$ & $\begin{array}{l}26.6 \% \\
73.4 \%\end{array}$ \\
\hline Others & $30 \% * * *$ & $23 \% * * *$ & $15 \% * * *$ & $\mathrm{~s}(\text { Cal. week })^{4}+$ nest & $38 \%$ & - \\
\hline
\end{tabular}

in general, a better predictor of diet than was reproductive week and a much better predictor than nest identity. Explanatory power of models fitted to particular species was greater than that of models fitted to prey groups (Table 2). Consumption of three species showed great fluctuations and peaked at different times within the breeding period (Fig. 2): $G$. gryllotalpa was consumed in large numbers during the first seven calendar weeks of the breeding season. After that, it completely disappeared from the diet, and E. ephippiger became the primary prey. In the last weeks of the breeding season (calendar week 11 to 15), Decticus albifrons was the most frequent prey. Mice were found every week, and were important in terms of biomass (Table 1). Consumption of mice peaked in reproductive weeks 9 and 10 (between peaks of the two bush-cricket species mentioned above), when 21 out of 48 mice were consumed.

Some prey groups appeared to be "refuge-prey," consumed regularly in low frequencies, with small fluctuations (Fig. 2) that did not seem to correspond to peaks in availability. Among them, Acrididae was important in the first calendar week (due mainly to the contribution of Aiolopus sp.), decreasing thereafter until Locusta migratoria increased in the diet. Gryllidae, which was composed mainly of a single species (Gryllus campestris), peaked during the third calendar week of the breeding period, in a pattern sim- ilar to that of the other fossorial species (earthworms and G. gryllotalpa). Gryllus campestris also nearly disappeared from the diet thereafter, but appeared again during the last weeks of the nestling period. Beetles were consumed throughout the breeding season, with no significant increase or decrease.

Mean prey weight increased as the breeding season advanced, peaking around calendar weeks 12-13 and declining nonsignificantly thereafter (Fig. 3). The best model for this variable included a second degree spline fitted to reproductive week and the term nest (Table 3).

Prey richness peaked at calendar week 4, decreasing afterward, but reaching a plateau between weeks 9 to 14 (Fig. 3). The best model for this variable included a fourth degree spline fitted to reproductive week.

\section{Discussion}

As documented in previous studies, Lesser Kestrels fed mainly on insects, with the addition of some vertebrates (mostly mice). Primary prey species reported in this study were also found to be significant in the few previous studies that focused on species composition (Rocha 1998, Choisy et al. 1999, Lepley et al. 2000).

Lesser Kestrel diet changed markedly during the breeding season, in terms of prey composition, 

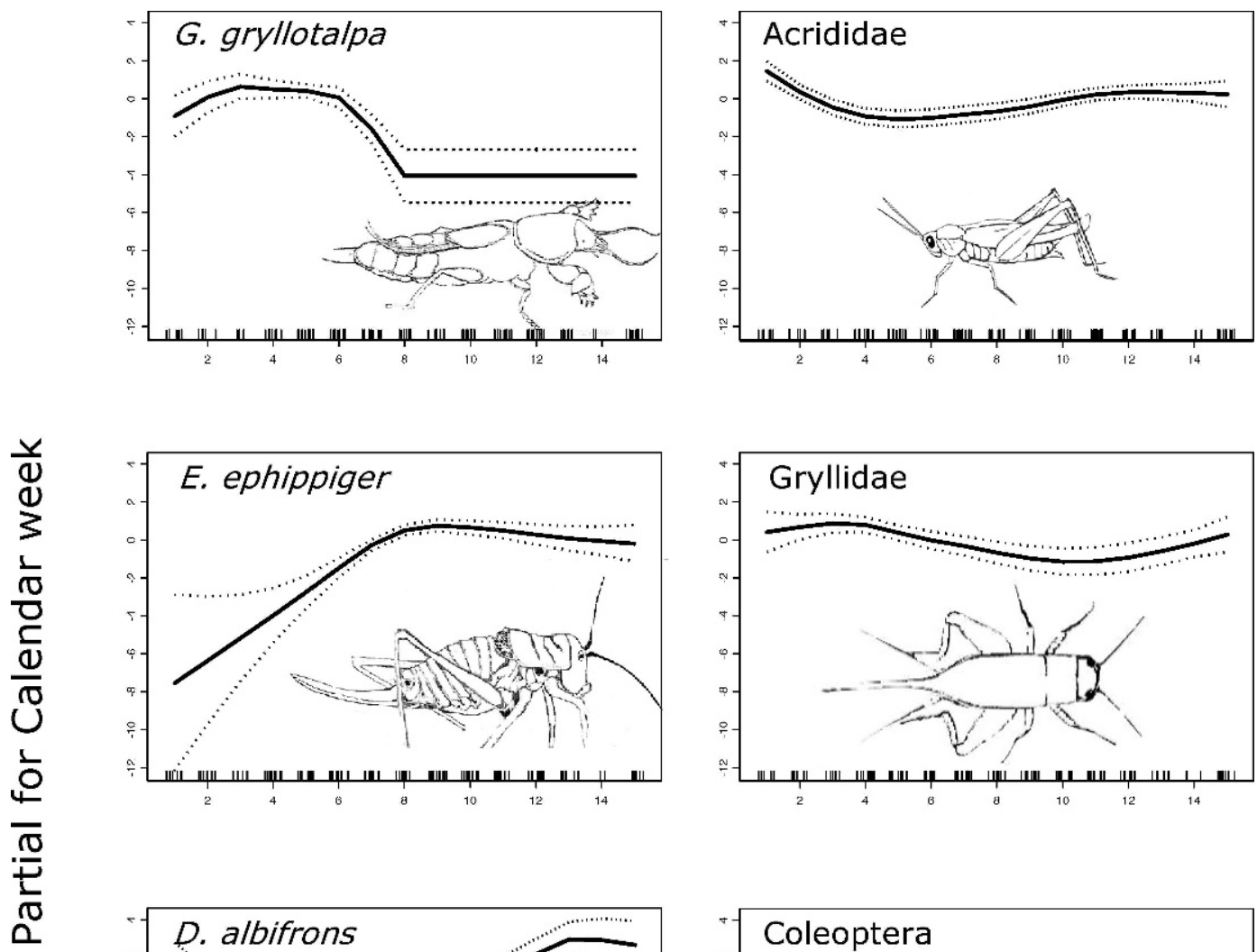

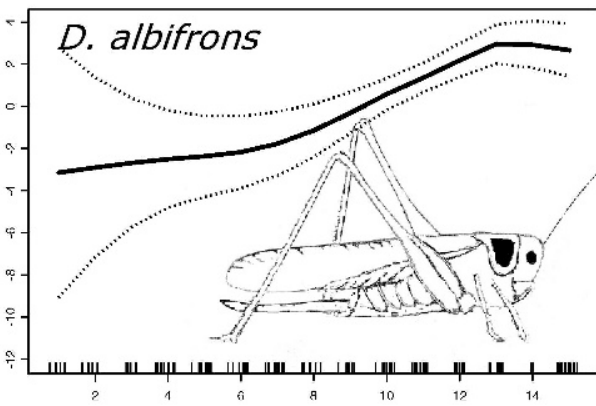

Calendar week

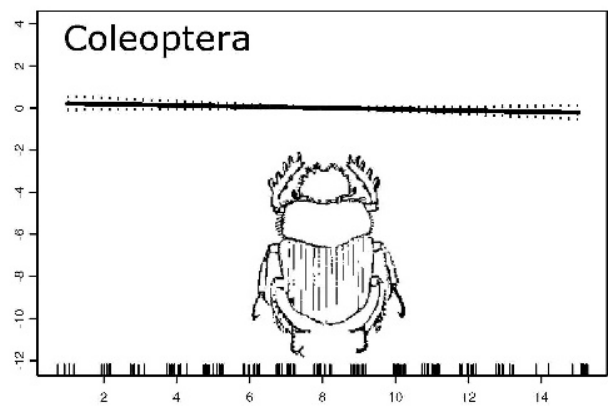

Calendar week

Figure 2. Smoothed splines fitted to calendar week for preferred prey (left) and "refuge" prey (right). Because of the total absence of G. gryllotalpa after week 7, model was only fitted to this period. Although reproductive week was a better predictor for some prey species, calendar week was used to facilitate comparison among them. The rugplot on the x-axis indicates the density of data points.

mean prey weight, and prey richness. Consumption of different prey species peaked at different times, the mean prey weight increasing as the breeding season advanced and peaking during the nestling period, and prey richness decreasing with a minimum during the nestling period. This is, in general terms, in accordance with ecological energetics of similar species (Masman et al. 1988): increasing en- ergetic demands during the breeding period (peaking during the nestling phase) make it optimal for kestrels to prey upon larger invertebrate prey, which are probably less numerous than smaller prey. Increasing temperatures during late spring and early summer allow arthropods to grow more quickly so that bigger individuals become available later in the season. Late availability of bigger prey species may 

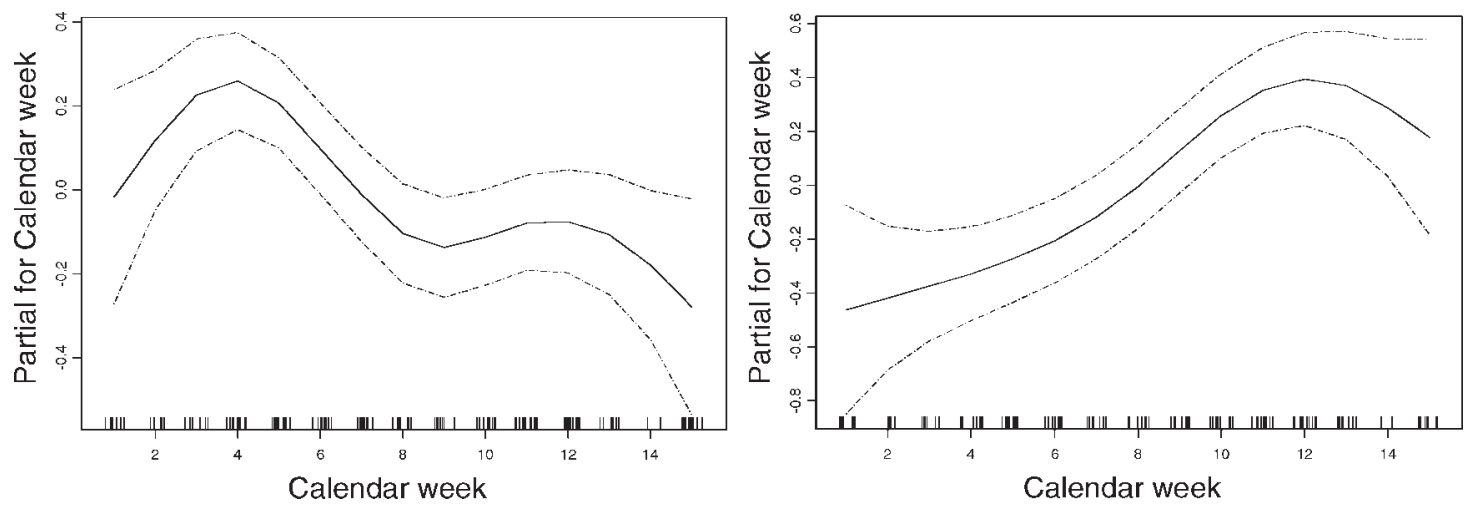

Figure 3. Smoothed splines fitted to calendar week for prey richness (left) and mean prey weight (right) in Lesser Kestrel pellets. Calendar week instead of reproductive week was used to better compare with prey models. The rugplot on the $\mathrm{x}$-axis indicates the density of data points.

explain why Lesser Kestrels do not begin laying eggs until April, despite their early arrival from the wintering grounds in mid-February. Mean prey weight during incubation was higher than that during the courtship, lending support to those studies documenting the energetic cost associated with incubation. Alternatively, potential surplus energy gained during incubation may be stored as fat that allows adults to better face the energetic demands of the nestling period.

Despite the decreasing trend of prey richness indicating a stronger prey selection during the nestling period, we also found certain prey species that seemed to be preferred by Lesser Kestrels during the courtship and incubation periods. Gryllotalpa gryllotalpa was the primary species consumed during courtship (see also Choisy et al. 1999), when males feed females, helping them to reach the body condition necessary to produce and lay eggs (Donázar et al. 1992). Gryllotalpa gryllotalpa is a lipid-rich species $(8.67 \%$ of its dry matter; for comparison, Microtus sp. voles contain $1.94 \%$ lipids; Juillard in Lepley et al. 2000) that probably allows rapid weight gains. This species disappeared from diet after calendar week 7 , probably because it became inaccessible for kestrels due to either species' phenology or ab- sence of plowing of agricultural fields at that time. Fields devoted to sunflower crops are normally plowed in early spring, and this may explain the occurrence of mole crickets, and other fossorial species such as earthworms in the diet. A previous study of a Portuguese Lesser Kestrel colony $140 \mathrm{~km}$ away from the one we studied documented a significant correlation (96\%) between abundance of G. gryllotalpa in field samples and its occurrence in Lesser Kestrel pellets until mid-May, when the species virtually disappeared from both field samples and pellets (Ventim et al. 2004). This suggests that the species phenology determines its occurrence in Lesser Kestrel diet and explains why calendar week was the best single predictor for the occurrence of this species in the diet. The additional term "nest" improved explanatory ability of the model probably because the breeding pair that started breeding latest (Fig. 1) did not consume this species.

The incubation period was characterized by the sudden appearance and heavy consumption of $E$. ephippiger that peak during the incubation period. Afterward, and especially during the last calendar weeks of the breeding period, D. albifrons became the primary prey species. This temporal variation in

Table 3. Significance and percentage explained deviance (E.D.) by the AIC-selected form of each predictors of mean prey weight and prey richness in Lesser Kestrel pellets. The best model and its E.D. are also indicated. Terms fitted with a smooth spline are denoted with an "s" before them, the exponent indicating the degrees of freedom of the spline. Significance key: $* * *=<0.001 ; * *=<0.01 ; *=<0.05$; N.S. $=$ nonsignificant.

\begin{tabular}{lccccc}
\hline Response Variable & Calendar Week & Reproductive WeEk & Nest ID. & Best Model & D.E. \\
\hline Mean prey weight & $18 \% * * *$ & $16 \%$ & N.S. $6 \%$ & s(Rep. week) $)^{2}+$ nest & $22 \%$ \\
Prey richness & $18 \% * * *$ & $25 \% * * *$ & N.S. $2 \%$ & s(Rep. week) & $25 \%$ \\
\hline
\end{tabular}


the occurrence of these species, their high frequency ( $18 \%$ of the total), and their large size (they were among the largest insect prey species found in this study, accounting for $47 \%$ of the total biomass; Table 1) suggest that they are preferred prey species. Conversely, beetles, field crickets, and the majority of grasshoppers (excluding large locusts) are smaller and probably serve as alternative prey species that are consumed when preferred species are less available in the field. Accordingly, the patterns of temporal variation of alternative prey in diet were much less pronounced than those of preferred prey (see Fig. 2). Nonetheless, as a caveat, it should be noted that other than crickets (mainly field crickets [ $G$. campestris]), alternative prey were not analyzed at the species level, and models fitted to species were better than those fitted to groups, which may partially explain differences in the degree of temporal fluctuations. Obviously, particular prey species will show their own phenology while grouping species may mask the phenology of individual species.

An interesting finding was the importance of vertebrates to the Lesser Kestrel diet during the first weeks of the nestling phase, between the peaks of $E$. ephippiger and D. albifrons. It remains a challenge to determine whether this constitutes a response to optimal foraging strategies, feeding preferences, or nestlings' requirements.

Calendar and reproductive week showed similar explanatory abilities, probably because of correlation between these two variables. As discussed above, prey availability in the field (i.e., calendar week) was the best predictor of mole cricket consumption, whereas reproductive week was a better predictor than calendar week for consumption of D. albifrons. However, this is probably because nearly all pairs were rearing nestlings when this species became available in the field. In a previous study in the area, researchers collected fresh pellets in the middle of the nestling period and found a smaller proportion of this species in Lesser Kestrel diet (Rodríguez 2004). This proportion was higher in northern colonies (Rocha 1998, Lepley et al. 2000), which start breeding later, when the prey species is probably more available.

Thus, it remains unclear how energetic demands of the breeding period influence prey selection, probably because of the low number of nests considered in our study. Further studies with more nests and different phenology may help clarify this question.

Nest identity had little explanatory value, indicating that individual variation in diet composition was low. We could not evaluate the effect of interannual fluctuation in prey abundance in this study, but we were able to show patterns of diet variation within one breeding season. This approach allowed us to determine primary preferred species for the Lesser Kestrel, not only during the nestling period, but also during courtship and incubation. As detailed in previous studies, prey availability in the study colony was relatively high (Rodríguez and Bustamante 2008), allowing for a high reproductive rate (Rodríguez and Bustamante 2003). Lower reproductive outputs in other colonies of the same population have been associated with prey scarcity (Negro 1997), and, in a 3-year study, Rodríguez (2004) documented a lower proportion of these preferred species in colonies with lower breeding success (Rodríguez et al. 2006). From a conservation perspective, we recommend that further studies investigate habitat requirements of these preferred prey species, in order to improve the foraging conditions for the endangered Lesser Kestrel.

\section{ACKNOWLEDGMENTS}

We are indebted to Maria del Mar Delgado, who greatly contributed to pellet analyses. José Luis Yela and Jorge M. Lobo helped us identify some insect remains. Luis Tapia was supported by the Postdoctoral Fellowship (Angeles Alvariño) from the Galician Government (Xunta de Galicia) during his stay at the Doñana Biological Station, CSIC. Anthony van Zyl, Zárybnická Markéta, and an anonymous referee provided helpful comments on a previous version of the manuscript.

\section{Literatured Cited}

Anderson, P.C., O.B. KoK, And B.H. Erasmus. 1999. Diet, body mass and condition of Lesser Kestrels Falco naumanni in South Africa. Ostrich 70:112-116.

BirdLifE InTERnAtionAL. 2004. European bird populations: estimates and trends. BirdLife International, Cambridge, U.K.

Choisy, M., C. Conteau, M. Lepley, N. Manceau, and G. YAU. 1999. Régime et comportement alimentaires du falcon crecerellette Falco naumanni en Crau en période prénuptiale. Alauda 67:109-118.

Chynery, M. 1988. Insectos de España y Europa. Omega, Barcelona, Spain.

Clemente, M.E., M.D. García, and J.J. Presa. 1987. Clave de los géneros de saltamontes ibéricos (Orthoptera, Caelifera). Universidad de Murcia, Murcia, Spain.

Crawley, M.J. 2002. Statistical computing: an introduction to data analysis using S-plus. Wiley, Chichester, U.K.

Dijkstra, C., S. Daan, T. Mejer, A.J. Cavé, And R.P.B. FopPEN. 1988. Daily and seasonal variations in body mass of the kestrel in relation to food availability and reproduction. Ardea 76:127-140 
DonÁzAr, J.A., J.J. Negro, AND F. Hiraldo. 1992. Functional analysis of mate-feeding in the Lesser Kestrel Falco naumanni. Ornis Scandinavica 23:190-194.

Fernández, R., A. Martín, F. Ortega, And E.E. Alés. 1992. Recent changes in landscape structure and function in a Mediterranean region of SW Spain (1950-1984). Landscape Ecology 7:3-18.

Franco, A. AND J. ANDRADA. 1977. Alimentación y selección de presa en Falco naumanni. Ardeola 23:137-187.

Hastie, T.J. AND R.J. TibshiRANi. 1990. Generalized additive models. Chapman and Hall, London, U.K.

Johnson, J.B. AND K.S. OMLAND. 2004. Model selection in ecology and evolution. Trends in Ecology and Evolution 19:101-108.

KoK, O.B., A.C. KoK, And C.A. VAn EE. 2000. Diet of the migrant Lesser Kestrel Falco naumanni in their winter quarters in South Africa. Acta Ornithologica 35:147-151.

KopIJ, G. 2007. Seasonal and annual dietary changes in Lesser Kestrels Falco naumanni wintering in Lesotho. Ostrich 78:1-5.

Lepley, M., L. Brun, A. Foucart, and P. Pilard. 2000. Régime et comportement alimentaires du falcon crecerellette Falco naumanni en Crau en période de reproduction et post-reproduction. Alauda 68:177-184.

Masman, D., S. DaAn, And H.J.A. Beldhuis. 1988. Ecological energetics of the kestrel: daily energy expenditure throughout the year based on time-energy budget, food intake and doubly labeled water methods. Ardea 76:64-81.

Mathsoft, InC. 1999. S-PLUS user's guide. Data analysis products division, Seattle, WA U.S.A.

Marti, C.D., M. Bechard, AND F.M. Jacksic. 2007. Food habits. Pages 129-149 in D.M. Bird and K.L. Bildstein [EDS.], Raptor research and management techniques. Hancock House Publishers, Blaine, WA U.S.A.

Negro, J.J. 1997. Falco naumanni Lesser Kestrel. Birds of the Western Palearctic Update 1:49-56.
AND F. Hiraldo. 1993. Nest-site selection and breeding success in the Lesser Kestrel Falco naumanni. Bird Study 40:115-119.

Newton, I. 1979. Population ecology of raptors. T. and A.D. Poyser, London, U.K.

1998. Population limitation in birds. Academic Press, London, U.K.

Peet, N.B. and U. Gallo-Orsi. 2000. Action plan for the Lesser Kestrel Falco naumanni. Council of Europe and BirdLife International, Cambridge, U.K.

RochA, P.A. 1998. Dieta e comportamento alimentar do Peneireiro-de-dorso liso Falco naumanni. Airo 9:40-47.

RoDRÍGUEZ, C. 2004. Factores ambientales relacionados con el éxito reproductivo del Cernícalo primilla. Cambio climático e intensificación agraria. Ph.D. dissertation, University of Salamanca, Salamanca, Spain. AND J. Bustamante. 2003. The effect of weather on Lesser Kestrel breeding success: can climate change explain historical population declines? Journal of Animal Ecology 72:793-810.

AND —. 2008. Patterns of Orthoptera abundance and Lesser Kestrel conservation in arable landscapes. Biodiversity and Conservation 17:1753-1764.

, K. Johst, And J. Bustamante. 2006. How do crop types influence breeding success in Lesser Kestrels through prey quality and availability? A modelling approach. Journal of Applied Ecology 43:587-597.

Ventim, R., A. Cordeiro, R. Alcazar, P. Rocha, A. Franco, AND J. PAlmeIRIM. 2004. Importance of Gryllotalpa sp. in the Lesser Kestrel's diet. International Workshop on the Conservation of Lesser Kestrel. Castro Verde, Portugal.

ZAHRADNiK, J. 1990. Guía de los Coleópteros de España y de Europa. Ediciones Omega, Barcelona, Spain.

Received 19 May 2009; accepted 11 January 2010 Associate Editor: Vincenzo Penteriani 